Arch. Tierz., Dummerstorf 49 (2006) 6, 615-616

${ }^{1}$ Institute of Genetics, Vetsuisse Faculty, University of Berne, Bremgartenstr. 109a, 3001 Berne, Switzerland

${ }^{2}$ Department of Large Animal Clinical Sciences, Western College of Veterinary Medicine, University of

Saskatchewan, Saskatoon, SK, S7N 5B4, Canada

CORD DRÖGEMÜLLER ${ }^{1}$, CHRISTY S. BARLUND ${ }^{2}$, COLIN W. PALMER ${ }^{2}$ and TOSSO LEEB ${ }^{1}$

\title{
A novel mutation in the bovine $E D A$ gene causing anhidrotic ectodermal dysplasia (Brief report)
}

(Eine neue ursächliche Mutation für anhidrotische ektodermale Dysplasie im bovinen EDA Gen)

Background: X-linked anhidrotic ectodermal dysplasia (EDA), also called hypohidrotic ectodermal dysplasia (HED), represents a group of similar phenotypes described in humans, the tabby mouse mutant, dog, and cattle (KERE et al., 1996; SRIVASTAVA et al., 1997; CASAL et al., 2005; DRÖGEMÜLLER et al., 2001, 2002). EDA is characterised by the hypoplasia or absence of hair and eccrine glands in addition to dental abnormalities. Ectodysplasin A1 and A2, the two isoforms encoded by the EDA gene, are transmembrane protein members of the tumor necrosis factor (TNF) family and deleterious mutations in the human, murine, canine, and bovine EDA gene, respectively, result in manifestations of EDA.

Procedures: We hypothesised X-linked recessive inheritance in a single male Red Angus-Charolais-Simmental crossbred calf with confirmed diagnosis of congenital EDA (BARLUND et al., 2006). Applying the candidate gene approach we screened genomic DNA of this affected calf and one healthy control animal for possible EDA deletions, insertions or single nucleotide polymorphisms. We individually amplified all 8 exons and flanking sequences of the bovine EDA gene using the PCR primers previously described (DRÖGEMÜLLER et al., 2001, 2002). PCR products were bidirectionally re-sequenced on an ABI 3730 capillary sequencer (Applied Biosystems, Rotkreuz, Switzerland) using the PCR primers as sequencing primers with the ABI BigDye Terminator Sequencing Kit 3.1 (Applied Biosystems, Rotkreuz, Switzerland). Sequence data were analysed with Sequencher 4.6 (GeneCodes, Ann Arbor, MI, USA).

Results: A single $\mathrm{C}>\mathrm{T}$ transition was found at position +730 of the bovine $E D A$ coding sequence (+730C $>$ T) (GenBank Acc. No. AJ278907). The site of the mutation corresponds to position 24 of exon 6 in the bovine EDA gene and is located within a CpG dinucleotide (Fig.). This base substitution causes a nonsense mutation of arginine (R) into a stop codon (X) at amino acid position 244 (R244X). The affected calf was hemizygous for the mutated allele. Unfortunately, a familial segregation study was impossible as no samples of related animals were available. All other EDA exons in the affected calf were normal and did not show any alterations in comparison to the control animal. On the protein level, the observed EDA mutation leads to a truncated protein that lacks the functional important C-terminal TNF-like signalling domain of the ectodysplasin A1 and A2 proteins. Mutations in the TNF homology domain impair binding of both splice variants to their receptors (SCHNEIDER et al., 2001). Therefore, it is highly plausible that the phenotype in the EDA-affected calf is indeed caused by the nonsense R244X mutation of the EDA gene. The aberrant ectodysplasin 1 molecule represents a loss of function mutant. In humans, many different mutations within the EDA gene are known to result in phenotypes comparable to the one 
described herein. Interestingly, one report described two human patients, who also had a $\mathrm{C}>\mathrm{T}$ transition in codon 244 leading to a truncated protein similar to the genetic lesion observed in the EDA cattle of this study indicating that a similar mutation has occurred independently in cattle and humans (VINCENT et al., 2001).

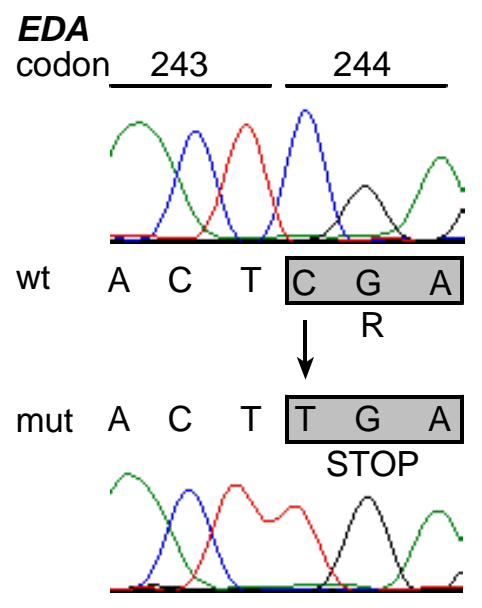

Figure: Sequence analysis of genomic DNA of the investigated animals. The upper sequence is from a normal control animal (wt). The lower sequence is from the affected calf (mut). An arrow denotes the position of the $\mathrm{C}>\mathrm{T}$ transition located at position 24 of bovine EDA exon $6(+730 \mathrm{C}>\mathrm{T})$ causing the R244X nonsense mutation.

The R244X mutation described in the current report represents the third reported EDA mutation in cattle. The first two reported EDA mutations, a large genomic deletion of exon 3 and a splice site mutation (IVS8 $+2 \mathrm{~T}>\mathrm{G}$ ), occurred in German Holstein cattle (DRÖGEMÜLLER et al., 2001). All known bovine EDA mutations probably represent complete loss of function mutants that might be useful animal models for the investigation of the ectodysplasin signalling pathways.

Acknowledgments: We are grateful to B. Colomb for expert technical assistance and to S.M. Schmutz for constructive discussions and the DNA sample.

\section{References}

CASAL, M.L.; SCHEIDT, J.L.; RHODES, J.L.; HENTHORN, P.S.; WERNER, P.:

Mutation identification in a canine model of X-linked ectodermal dysplasia. Mamm. Genome 16 (2005), 524-531

DRÖGEMÜLLER, C.; DISTL, O.; LEEB T.:

Partial deletion of the bovine ED1 gene causes anhidrotic ectodermal dysplasia in cattle. Genome Res. 11 (2001), 1699-1705

DRÖGEMÜLLER, C.; PETERS, M.; POHLENZ, J.; DISTL, O.; LEEB, T.:

A single point mutation within the $E D 1$ gene disrupts correct splicing at two different splice sites and leads to anhidrotic ectodermal dysplasia in cattle. J. Mol. Med. 80 (2002), 319-23

KERE, J.; SRIVASTAVA, A.K.; MONTONEN, O.; ZONANA, J.; THOMAS, N.; FERGUSON, B.; MUNOZ, F.; MORGAN, D.; CLARKE, A.; BAYBAYAN, P.; CHEN, E.Y.; EZER, S.; SAARIALHO-KERE, U.; DE LA CHAPELLE, A.; SCHLESSINGER, D.:

X-linked anhidrotic (hypohidrotic) ectodermal dysplasia is caused by mutation in a novel transmembrane protein. Nat. Genet. 13 (1996), 409-416

SCHNEIDER, P.; STREET, S.L.; GAIDE, O.; HERTIG, S.; TARDIVEL, A.; TSCHOPP, J.; RUNKEL, L.; ALEVIZOPOULOS, K.; FERGUSON, B.M.; ZONANA, J.:

Mutations leading to X-linked hypohidrotic ectodermal dysplasia affect three major functional domains in the tumor necrosis factor family member ectodysplasin-A. J. Biol. Chem. 276 (2001), 18819-18827

SRIVASTAVA, A.K.; PISPA, J.; HARTUNG, A.J.; DU, Y.; EZER, S.; JENKS, T.; SHIMADA, T.; PEKKANEN, M.; MIKKOLA, M.L.; KO, M.S.H.; THESLEFF, I.; KERE, J.; SCHLESSINGER, D.:

The Tabby phenotype is caused by mutation in a mouse homologue of the EDA gene that reveals novel mouse and human exons and encodes a protein (ectodysplasin-A) with collagenous domains. Proc. Natl. Acad. Sci. U. S. A. 94 (1997), 13069-13074

VINCENT, M.C.; BIANCALANA, V.; GINISTY, D.; MANDEL, J.L.; CALVAS, P.:

Mutational spectrum of the ED1 gene in X-linked hypohidrotic ectodermal dysplasia. Eur. J. Hum. Genet. 9 (2001), 355-363 